\title{
ADVANCES IN TUMOR MARKERS FOR THE EARLY DIAGNOSIS OF PAPILLARY THYROID CARCINOMA
}

\author{
HUANG GUO-QING ${ }^{1}$, LIU YING ${ }^{2}$, CAO DI-FEI ${ }^{1}$, GONG YU1 ${ }^{1}$, SU DAN ${ }^{1}$, ZHAO JIN-HAI ${ }^{1}$, WANG LEI ${ }^{1}$ \\ ${ }^{1}$ Institute of Advanced Technology, Heilongjiang Academy of Sciences, Dao Wai District, Nan Ma Road, No.135 150020 Harbin, \\ China, ${ }^{2}$ Medical University Pharmaceutical, Harbin 150090, China \\ Email: huangguoqing0921@163.com
}

Received: 24 Apr 2016 Revised and Accepted: 29 May 2016

\begin{abstract}
Papillary Thyroid Carcinoma (PTC) is a common endocrine malignancy and mostly is found in women. Different pathological types of PTC have different biological behaviors. The hidden onset results in difficulties to diagnose the early PTC. With the development of the molecular biology, increasing the number of researchers is a focus on tumor markers. The sensitivity and specificity of these tumor markers are helpful for early diagnosis and therapy of PTC. This review is oriented towards the finding of the potent thyroid cancer markers have enhanced sensitivity and specificity, with diagnostic, prognostic and therapeutic efficiency.
\end{abstract}

Keywords: Papillary thyroid carcinoma, Tumor markers, Galectin-3, Ki67, HBME-1, CK19, VEGF-C, Claudin-1

(C) 2016 The Authors. Published by Innovare Academic Sciences Pvt Ltd. This is an open access article under the CC BY license (http://creativecommons.org/licenses/by/4.0/) DOI: http://dx.doi.org/10.22159/ijpps.2016v8s2.15221.

\section{INTRODUCTION}

Thyroid carcinoma is the most frequent endocrine cancer in the last $30 \mathrm{y}$; the incidence of thyroid carcinoma has been increasing rapidly which has caused a wide attention. The new cases of thyroid carcinoma account for $1 \%-5 \%$ of all cancer, particularly in women [1]. Rahib L [2] shows that by 2030, the incidence of thyroid carcinoma will rise to a fourth of malignant tumors. In 2010, the average annual percentage change (AAPC) of men and women were 5.4 and 6.5; the number of thyroid cancer cases of men and women were 11000 and 34000 , and it would be increased to 39000 and 144000 cases [2-4]

In addition to the medullary carcinoma, the vast majority of thyroid carcinoma originated in follicular epithelial cells. Thyroid carcinoma can be classified according to their histopathological characteristics, such as, PTC, follicular thyroid cancer (FTC) medullary thyroid cancer (MTC), anaplastic thyroid cancer (ATC), poorly differentiated thyroid cancer, thyroid lymphoma, squamous cell thyroid carcinoma and sarcoma of thyroid. Among them, PTC and FTC belong to differentiated thyroid carcinoma (DTC). PTC is the most common thyroid tumor accounts for 79\%-94\% of total thyroid tumor followed by FTC (15\%), MTC (5\%) and ATC (1\%) tumor (ATC is primarily rare and highly aggressive subsets), which is generally treated by surgical resection and radio-iodine therapy [5].

Thyroid cancer is as aggressive in nature as other cancers, where complete remission can be achieved by early diagnosis and proper treatment. For the majority of thyroid cancer patients with good prognosis, the 5, 10 and 30-year survival rates were approximately $98 \%, 93 \%$ and $76 \%$ [6]. In the early stage, differentiated thyroid cancer (PTC and FTC) shows better prognosis with 5-year survival rate varies from $85-95 \%$. However, in a later stage (stage-IV) the prognosis is very poor with a 5-year survival rate varies from $24-47 \%$ [7]. Nevertheless, thyroid cancer is easy to relapse, approximately $20 \%$ of the patients have to do two or more time surgical [8]. Anaplastic thyroid cancer is the most aggressive of all cancer with 9\% 5-year survival rate in all the stages and 100\% mortality. Therefore, more attention should be paid to its early diagnosis

The majority of the PTC are being diagnosed by palpation, ultrasound, scintigraphy, fine needle aspiration biopsy (FNAC), histology, immunohistochemistry (IHC), imaging modalities like $\mathrm{X}$-ray, and computed tomography (CT) in clinical. However, these methods can not distinguish between benign and malignant nodules conditions; and has certain limitations. Just like variants of papillary and follicular cancer creates confusion among pathologists, where the morphological features are indistinguishable. In order to address this problem, several tumor markers are proposed and their efficiency in thyroid cancer diagnosis, treatment and prognosis are being evaluated which look forward to apply to early diagnosis of PTC or prognostic prediction in PTC patients, such as Galectin-3(GAL-3), Hector battifora mesothelial epitope-1(HBME-1), cytokeratin-19 (CK19), Ki67, vascular endothelial growth factor-C (VEGF-C) and Claudin-1 [9]. They were first preferred in many hospitals for their ease of use.

In this article, we have reviewed their recent development and the prospective value of the combination of multiple tumor markers in thyroid cancer, which may be helpful for the early diagnosis and the prognostic monitoring of patients with PTC.

The most common of the aggressive variant of PTC is the tall cell variant. PTC can be onset in any age, which is more common in children or younger female. (Some patients had done neck-X-ray therapy in childhood). PTC grow slowly, could be confined to the Thyroid for several years. The lesion could spread to other parts of thyroid and neck lymph node from the primary site through lymphatic vessel within the thyroid. Moreover, it could be confined for several years, therefore, it is easy to overlook. Extra-thyroid extension, late regional metastases, and distant metastases may be risk factors for early death from PTC [10]. In summary, the incidence tendency of PTC is increasing year by year, and now finding some biomarkers to assist diagnosis of PTC has become a hotspot.

Galectin-3

Galectin family members show altered expression at the mRNA level in PTC. Significant expression differences in all tested galectin family members $(1,2,3,4,7,8,9,10$ and 12) were noted for mRNA in PTC, with and without lymph node metastasis. Overexpression of galectin-1 and 3 proteins were noted in PTC with lymph node metastases. Galectin-1 protein was more strongly expressed than galectin-3 protein in PTC. Galectin-3 is a $\beta$-galactoside binding animal lectin which participates in cell-cell and cell-matrix adhesion, cell growth and cell cycle regulation, neoplastic transformation, metastasis, cellular damage reparation and apoptosis [11]. It has been noted to be expressed in PTC and transformed thyroid cell lines but not in normal thyroid cells. It 
could be considered one of the most valuable biomarkers for identifying the benign and malignant thyroid carcinoma. It was demonstrated by Murphy KM [12] that Gal-3 is highly expressed in PTC, and less in normal tissue or benign lesions. Gal-3 have a highly sensitivity but the specificity is lowly relatively in the differential diagnosis of benign thyroid carcinoma, malignant thyroid carcinoma and normal tissue, at the same study found that Gal-3 could become a potential therapeutic target for invasive PTC. Bartolazzi A [13] was differential diagnosis between benign and malignant thyroid by Gal-3, and the sensitivity and specificity were $100 \%$ and $89.65 \%$ in the diagnosis of PTC. The Gal-3 of 183 cases has detected which were indeterminate before operative diagnosis through FNAC using environmental scanning electron microscope immuno-gold labeling technique (ESEM-IGL), and the result shows that the sensitivity is $71.2 \%$, the specificity is $53.3 \%$, and the diagnosis rate is $61.2 \%$, which was similar to the immunohistochemistry [14]. Patients with thyroid carcinoma had significantly higher serum concentration of galectin-3 than those with benign thyroid lesions (papillary hyperplasia and thyroid adenoma) and normal subjects $(\mathrm{P}<0.001)$; in patients with papillary thyroid carcinoma, galectin-3 positivity in the tumor tissue was associated with a significantly higher serum galectin-3 level in comparison with the negative cases $(\mathrm{P}<0.05)[15]$.

\section{Ki67}

Ki67 expression in a variety of malignant tumors than normal tissues. Clinical research shows that Ki67 could react the proliferate activity of thyroid tumor. Previously studies suggest that the proliferation index of Ki67 in PTC was higher than follicular adenoma, nodular goiter, and normal thyroid tissue; nevertheless, Song Q [16] has found that the positive expression rate of Ki67 in PTC was 40.59\% (179/441) through immunehistochemical, and there are no significant difference between PTC and benign thyroid lesions.

Therefore, Ki67 can discriminate PTC, and benign thyroid disease is still controversial. In addition, Lee YS [17] also has shown that there are no significant correlation between tumor clinicopathological parameter and Ki67 expression in PTC. The expression of Ki67 in PTC was related to tumor size, invasion by a membrane and cervical lymph node metastasis, and could be the important indicator for judging clinical progress and estimating prognosis. And then, $\mathrm{Ki}-67$ has a higher correlation with BECN1 In routine studies [18].

\section{HBME-1}

HBME-1 is one of a monoclonal antibody, which was recently used for the thyroid pathology diagnosis, mainly expressed in human malignant epithelial mesothelioma cell membrane. Also, it's a specific marker in the surface of mesothelial cells microvilli, which plays an important role in tumor angiogenesis, tumor growth and tumor metastasis. HBME- 1 is mainly expressed in malignant tissues and very limited benign lesions. Compared with Gal-3 and CK19, HBME-1 has the highest specificity in the differential diagnosis of PTC and follicular adenoma; at the same time, it can be used to distinguish between FTC and PTC. de Matos LL [19] was meta-analysis 66 literatures which were gathered in MEDLINE and the Cochrane Library. They were confirmed that HBME-1 specificity $(83 \%)$ is higher than CKl9 $(73 \%)$ and Gal-3 (81\%) in the differential diagnosis of benign and malignant lesions of the thyroid, and combined with CK19 and Gal-3, can significantly improve the sensitivity and specificity to discriminate benign and malignant thyroid. The expression of HBME- 1 was $85.3 \%$ for the PTC group; for nonmalignant thyroid lesions group, the expression of these markers was $37.2 \%$. Furthermore, the expression of CK-19 and HBME-1 in PTCs was much higher than that in the benign thyroid lesions $(\mathrm{P}<0.05)$ [18]. All cases of macrofollicular, Warthin-like and diffuse sclerosing PTC variants were HBME-1 positive $(4 / 4,3 / 3,2 / 2 ; 100 \%$ respectively). Tall cell and solid PTC variants showed the diversity of staining $(2 / 3 ; 66.67 \%$ and $13 / 23$; $56.52 \%$ respectively), while PTCs with a mixed histological pattern containing insular areas were mainly weakly positive $(2 / 5$;
$40.0 \%$ [ [20]. For a single analyzed tumor marker, the sensitivity of HBME- 1 was $86 \%$ and the specificity was $100 \%$ [21]. Among 88 FNAs with histological control, the sensitivity of HBME-1 to predict PTC was $87.5 \%(28 / 32)$ and the specificity was $86 \%$ $(48 / 56)$. HBME-1 was the most specific $(97.9 \%)$ which was reviewed by specimens from 331 patients with PTC and 664 patients with benign thyroid nodules. In summary, HBME-1 has a relatively high specificity in differentiating benign and malignant thyroid lesions, and combined with other tumor markers may be better for diagnosis of papillary thyroid cancer.

\section{CK19}

Cytokeratin (CK) is a major component of the cytoskeleton, in these, CKI9 is a low molecular weight type I keratin, which was expressed in normal epithelial, also in a variety of epithelial origin tumors. CK19 has shown a higher sensitivity and lower specificity in a variety of epithelial tumor-derived, and it plays an important role in cell differentiation and tumor diagnosis, it is a useful marker for the identification of both types of PTC. Regarding the univariate set of tests, high expression of CK19 correlated significantly with age, multifocality, extrathyroidal extension, pT status and pTNM stage of PTC $(\mathrm{p}<0.05$ for all); multivariate analyses confirmed the significant association of high CK19 expression with extrathyroidal extension of PTC as well as with pTNM stage $(p<0.05$ and $p<0.01$, respectively) [22]. Recent studies have shown that CK19 was a focally expression in normal thyroid follicular, diffused strong expression in PTC, whereas expression or weak expression in benign thyroid lesion. The expression of CK-19 was $96.3 \%$ which was obtained from 257 patients with PTC, further, the expression of CK-19 in PTCs was much higher than that in the benign thyroid lesions $(\mathrm{P}<0.05)$ [18].

There are also study shows that the sensitivity of CK19 was $100 \%$, and the specificity was $56.25 \%$. CK19 were found to have high sensitivity (0.75) and specificity (0.95) for PTC. The studies by Song Q [16] show that the expression of CK19 in PTC was much higher than that in the nonmalignant or benign disease cases group $(p<0.05)$, which was $96.37 \%(425 / 441)$ in PTC and in the benign thyroid lesions group was $25.83 \%$ (39/151), also show that the diagnostic efficiency of CK19 for PTC was $96.37 \%$ (537/592). Bose D's [23] studies give that, all 22 (100\%) papillary carcinomas showed diffuse and strong (3tand 4+) CK19 expression, as well as $75 \%$ follicular adenomas and $50 \%$ multinodular goiters, were positive for CK19; however, it was of weaker intensity $(1+$ and $2+)$ and focal in distribution. CK19 expression levels differed vastly between nodes with and without metastatic cells, ddCt of CK19 in the genetic material extracted from nodes without metastatic was $9.97 \pm 4.20$, while in nodes with metastases ddCt was $0.91 \pm 4.20(p<0.0001)$ [24]. According to ROC analysis, CK19 can discriminate both types of PTC from other neoplasias of the thyroid gland $(p<0.05)$ [22]. Although greatest accuracy was gained for the identification of PTCcl (91.07\%), this marker was also helpful for distinguishing PTCfv from follicular thyroid adenomas (FTA) and FTC (accuracy 71.43 and $65.17 \%$, respectively), high expression of this protein predicts the aggressive behavior of PTC and can help in the identification of a particular subgroup of PTC patients with a potentially worse prognosis. Furthermore, CK19 could be played a role in extrathyroid tumor spread [25].

\section{Other potential PTC markers}

With high sensitivity and specificity, positive staining panel of Galectin-3, Ki67, HBME-1, CK19, VEGF-C have been proved to be the most promising and most frequently used molecular markers in identifying PTC, including both the classic (CPTC) and the follicular variant (FVPTC). However, there are some other biomarkers also have potential in accurate diagnosis and prognosis of thyroid carcinoma and have been reported. Efforts have been made to discover new tissue biomarkers and molecules measurable in body fluids with high sensitivity and specificity. Table 1 summarizes some of the most relevant molecular markers that can be used in the context of PTC. 
Table 1: Emerging biomarkers for diagnosis, prognosis, and prediction of PTC

\begin{tabular}{|c|c|c|c|c|c|}
\hline Biomarker & Characterization & Observation in PTC & Use & Detection & Reference \\
\hline $\begin{array}{l}\text { matrix } \\
\text { metalloproteinases-2 } \\
(\text { MMP-2) }\end{array}$ & $\begin{array}{l}\text { The MMPs play an important role } \\
\text { in tissue remodeling associated with } \\
\text { various physiological or pathological } \\
\text { processes. MMP-2 is thought to be } \\
\text { important in metastasis. }\end{array}$ & $\begin{array}{l}\text { The evaluation of MMP2 in } \\
\text { thyroid PTC appears to be a } \\
\text { borderline correlation was found } \\
\text { between the positive reaction of } \\
\text { tumor cells with the presence of } \\
\text { vascular invasion }\end{array}$ & $\begin{array}{l}\text { Diagnostic } \\
\text { Predictive }\end{array}$ & $\begin{array}{l}\text { Tissue } \\
\text { vascular }\end{array}$ & $\begin{array}{l}\text { [26] Wu G, } \\
\text { et al., 2013; }\end{array}$ \\
\hline Beclin-1 & $\begin{array}{l}\text { Beclin-1 participates in the } \\
\text { regulation of autophagy and has an } \\
\text { important role in development, } \\
\text { tumorigenesis, and } \\
\text { neurodegeneration }\end{array}$ & $\begin{array}{l}\text { BeclinN1 is a more specific marker } \\
\text { than HBME-1 in PTC and has a } \\
\text { higher correlation with Ki-67, and it } \\
\text { may play a role in tumorigenesis } \\
\text { and lymph node metastasis in PTC. }\end{array}$ & Diagnostic & Tissue & $\begin{array}{l}\text { [27] Yeşil C, } \\
\text { et al., 2015; }\end{array}$ \\
\hline $\begin{array}{l}\text { neutrophil } \\
\text { gelatinase-associated } \\
\text { lipocalin (NGAL) }\end{array}$ & $\begin{array}{l}\text { A small molecular weight secreted } \\
\text { protein which was originally found in } \\
\text { activated neutrophils. }\end{array}$ & $\begin{array}{l}\text { NGAL were positive in most PTC, } \\
\text { but were negative or showed } \\
\text { focal weak staining in control }\end{array}$ & $\begin{array}{l}\text { Diagnostic } \\
\text { Predictive }\end{array}$ & Tissue & $\begin{array}{l}\text { [28] Barresi } \\
\text { V, et al., } \\
\text { 2012; }\end{array}$ \\
\hline Claudin-1 & $\begin{array}{l}\text { Claudin- } 1 \text { Plays a major role in tight } \\
\text { junction-specific obliteration of the } \\
\text { intercellular space, through } \\
\text { calcium-independent cell adhesion } \\
\text { activity. }\end{array}$ & $\begin{array}{l}\text { High claudin- } 1 \text { protein expression } \\
\text { is specific for PTC and its regional } \\
\text { lymph node metastases }\end{array}$ & Diagnostic & Tissue & $\begin{array}{l}\text { [29] Ma } \mathrm{H}, \\
\text { et al.,2014; }\end{array}$ \\
\hline P16 & $\begin{array}{l}\mathrm{p} 16 \text { is a tumor suppressor protein, } \\
\text { that in humans is encoded by } \\
\text { the CDKN2A gene }\end{array}$ & $\begin{array}{l}\text { p16 gene alterations are common } \\
\text { and correlate with histological } \\
\text { features and biological } \\
\text { aggressiveness in PTC }\end{array}$ & Diagnostic & $\begin{array}{l}\text { Tissue } \\
\text { Cell } \\
\text { Blood }\end{array}$ & $\begin{array}{l}\text { [30] Do SI, } \\
\text { et al., 2015; }\end{array}$ \\
\hline p53 & $\begin{array}{l}\text { p53 has play a role in conserving } \\
\text { stability by preventing genome } \\
\text { mutation, it is a tumor } \\
\text { suppressor protein }\end{array}$ & $\begin{array}{l}\mathrm{P} 53 \text { is valuable to distinguish PTC } \\
\text { from other benign thyroid lesions, } \\
\text { but there is no correlation } \\
\text { between p } 53 \text { protein } \\
\text { overexpression and } \\
\text { clinicopathologic features. }\end{array}$ & Diagnostic & $\begin{array}{l}\text { Tissue } \\
\text { Cell } \\
\text { Blood }\end{array}$ & $\begin{array}{l}{[31] \text { Huang }} \\
\text { Y, et al., } \\
2014\end{array}$ \\
\hline p63 & $\begin{array}{l}\text { Tumor protein p } 63 \text { is a member of } \\
\text { the p53 family of transcription } \\
\text { factors }\end{array}$ & $\begin{array}{l}\text { Abnormal expression of p63 may } \\
\text { be important to promote the } \\
\text { progression and metastasis of PTC. }\end{array}$ & $\begin{array}{l}\text { Diagnostic } \\
\text { Predictive }\end{array}$ & $\begin{array}{l}\text { Tissue } \\
\text { Cell } \\
\text { Blood }\end{array}$ & $\begin{array}{l}{[32] \text { Hao Y, }} \\
\text { et al., 2013; }\end{array}$ \\
\hline Ras & $\begin{array}{l}\text { All Ras protein family members } \\
\text { belong to a class of protein called } \\
\text { small GTPase, and are involved in } \\
\text { transmitting signals within cells }\end{array}$ & $\begin{array}{l}\text { RAS-positive PTC was commonly } \\
\text { follicular variant, with infrequent } \\
\text { extrathyroidal extension and } \\
\text { lymph node metastasis. }\end{array}$ & $\begin{array}{l}\text { Diagnostic } \\
\text { Predictive }\end{array}$ & Tissue & $\begin{array}{l}\text { [33] Yip L, et } \\
\text { al., 2015; }\end{array}$ \\
\hline trefoil factor-3(TFF3) & $\begin{array}{l}\text { The functions of TFF3 are not } \\
\text { defined, but they may protect the } \\
\text { mucosa from insults, stabilize the } \\
\text { mucus layer and affect healing of the } \\
\text { epithelium. }\end{array}$ & $\begin{array}{l}\text { The high expression of TFF3 in } \\
\text { PTC is correlated with } \\
\text { carcinogenesis and progression, } \\
\text { may play a significant role in } \\
\text { evaluating the malignancy degree } \\
\text { and progression of PTC. }\end{array}$ & Diagnostic & Tissue & $\begin{array}{l}{[34] \text { Xue } \mathrm{G} \text {, }} \\
\text { et al., 2014; }\end{array}$ \\
\hline $\begin{array}{l}\text { matrix } \\
\text { metalloproteinases-9 } \\
\text { (MMP-9) }\end{array}$ & $\begin{array}{l}\text { The MMPs play an important role } \\
\text { in tissue remodeling associated with } \\
\text { various physiological or pathological } \\
\text { processes. MMP- } 9 \text { is thought to be } \\
\text { important in metastasis. }\end{array}$ & $\begin{array}{l}\text { The evaluation of active MMP-9 } \\
\text { by immunohistochemistry and } \\
\text { determination of its activation } \\
\text { ratio by gelatin zymography may } \\
\text { be a useful adjunct to the known } \\
\text { clinicopathological factors in } \\
\text { predicting tumor behavior. }\end{array}$ & $\begin{array}{l}\text { Diagnostic } \\
\text { Predictive }\end{array}$ & Tissue & $\begin{array}{l}{[35]} \\
\text { Marecko I, } \\
\text { et al., 2014; }\end{array}$ \\
\hline $\begin{array}{l}\text { matrix } \\
\text { metalloproteinases-13 } \\
\text { (MMP-13) }\end{array}$ & $\begin{array}{l}\text { MMP-13 is a recently identified } \\
\text { member of the MMPs, with broad } \\
\text { substrate specificity, and a potential } \\
\text { role in tumor metastasis and } \\
\text { invasion has been proposed. }\end{array}$ & $\begin{array}{l}\text { MMP- } 13 \text { may be associated with } \\
\text { thyroid tumour invasion and } \\
\text { metastasis, and it may be a } \\
\text { potential target for therapeutic } \\
\text { intervention }\end{array}$ & $\begin{array}{l}\text { Diagnostic } \\
\text { Predictive } \\
\text { therapeutic }\end{array}$ & Tissue & $\begin{array}{l}\text { [36] Wang } \\
\text { JR, et al., } \\
\text { 2013; }\end{array}$ \\
\hline $\begin{array}{l}\text { v-raf murine sarcoma } \\
\text { viral oncogene } \\
\text { homolog B1 } \\
\text { V600E(BRAF V600E) }\end{array}$ & $\begin{array}{l}\text { The B-Raf protein is involved in } \\
\text { sending signals inside cells, which } \\
\text { are involved in directing cell growth. }\end{array}$ & $\begin{array}{l}\text { Mutations of BRAF V600E was } \\
\text { identified in almost half of all } \\
\text { PTCs. An immunohistochemical } \\
\text { stain for BRAF is commercially } \\
\text { available and has been validated } \\
\text { in surgical specimens. }\end{array}$ & $\begin{array}{l}\text { Diagnostic } \\
\text { Prognostic }\end{array}$ & Tissue & $\begin{array}{l}{[37] \text { Rossi }} \\
\text { ED, et al., } \\
2015\end{array}$ \\
\hline E-cadherin & $\begin{array}{l}\text { The E-cadherin plays a key role in } \\
\text { cellular adhesion; loss of this } \\
\text { function has been associated with } \\
\text { greater tumour metastasis. }\end{array}$ & $\begin{array}{l}\text { E-cadherin expression is reduced in } \\
\text { papillary thyroid carcinoma, as } \\
\text { compared with native thyroid } \\
\text { parenchyma and papillary } \\
\text { hyperplasia. }\end{array}$ & Diagnostic & Tissue & $\begin{array}{l}\text { [38] Cheng } \\
\text { Y, et al., } \\
2015\end{array}$ \\
\hline $\begin{array}{l}\text { rearranged during } \\
\text { transfection(RET)/PTC }\end{array}$ & $\begin{array}{l}\text { RET is a tyrosine kinase receptor } \\
\text { whose ligands are neurotrophic } \\
\text { factors of the glial-cell line derived } \\
\text { neurotrophic factor family, including } \\
\text { neurturin, artemin and persefin. RET } \\
\text { activation is mediated via different } \\
\text { glycosyl phosphatidylinositol-linked } \\
\text { GRF_receptors. }\end{array}$ & $\begin{array}{l}\text { The current understanding of the } \\
\text { clinicopathologic role of RET/PTC } \\
\text { fusion proteins in PTC } \\
\text { development and progression } \\
\text { and the molecular mechanisms by } \\
\text { which RET/PTCs exert their } \\
\text { oncogenic effects on the thyroid } \\
\text { epithelium }\end{array}$ & $\begin{array}{l}\text { diagnostic } \\
\text { prognostic }\end{array}$ & Tissue & $\begin{array}{l}{[39]} \\
\text { Prescott JD, } \\
\text { et al., 2015; }\end{array}$ \\
\hline
\end{tabular}




\section{CONCLUSION}

In summary, each tumor markers in the diagnosis of PTC have a certain role, whereas there are some limitations of any single biomarker cannot be used as PTC diagnostic criteria. However, combined targeted therapeutic approach against different thyroid cancer biomarkers can reduce the side effect, improve therapeutic efficiency, and improve PTC diagnostic accuracy, which has been confirmed by many studies. Despite the recent positive progress observed in PTC incidence and mortality rates, efforts have to be made to achieve a better understanding of PTC precancerous lesions and of the factors triggering PTC development. This comprehension would enable a more proactive action against PTC progression. With the development of molecular biology techniques, the researches of PTC associated tumor markers have been gradually deepened.

The exploration of molecular targets and interactions for PTC treatment has been surprisingly rewarding and promising, with several benefits achieved in blocking progression and causing regression of metastases. Therefore, there are still exist problems about the biomarkers of PTC, such as, poor sensitivity and specificity in clinical. Looking for biomarkers of PTC with high sensitivity and specificity remains to be done.

\section{CONFLICT OF INTERESTS}

\section{Declared none}

\section{REFERENCES}

1. Kigbu JH, Nyango DD. A critical look on condoms. Niger J Med 2009;18:354-9.

2. Rahib L, Smith BD, Aizenberg R, Rosenzweig AB, Fleshman JM, Matrisian LM. Projecting cancer incidence and deaths to 2030 : the unexpected burden of the thyroid, liver, and pancreas cancers in the United States. Cancer Res 2014;74:2913-21.

3. Smith BD, Smith GL, Hurria A, Hortobagyi GN, Buchholz TA. Future of cancer incidence in the United States: burdens upon an aging, changing nation. J Clin Oncol 2009;27:2758-65.

4. Edwards BK, Noone AM, Mariotto AB, Simard EP, Boscoe FP, Henley SJ, et al. Annual report to the nation on the status of cancer, 1975-2010, featuring prevalence of comorbidity and impact on survival among persons with lung, colorectal, breast, or prostate cancer. Cancer 2014;120:1290-314.

5. Sipos JA, Mazzaferri EL. Thyroid cancer epidemiology and prognostic variables. Clin Oncol 2010;22:395-404.

6. Siegel RL, Miller KD, Jemal A. Cancer statistics. CA Cancer J Clin 2015;65:5-29.

7. Kim S, Schiff BA, Yigitbasi OG, Doan D, Jasser SA, Bekele BN, et al. Targeted molecular therapy of anaplastic thyroid carcinoma with AEE788. Mol Cancer Ther 2005;4:632-40.

8. Edafe O, Wadsley J, Harrison Bป Balasubramanian SP. Treatment-related morbidity in differentiated thyroid cancer-a survey of clinicians. Thyroid Res 2014;7:3.

9. Peng XG, Chen ZF, Zhang KJ, Wang PG, Liu ZM, Chen ZJ, et al. VEGF trapon inhibits tumor growth in papillary thyroid carcinoma. Eur Rev Med Pharmacol Sci 2015;19:235-40.

10. Hamzany Y, Soudry E, Strenov Y, Lipschitz N, Segal K, Hadar T, et al. Early death from papillary thyroid carcinoma. Am J Otolaryngol 2012;33:104-8.

11. Prasad ML, Huang Y, Pellegata NS, de la Chapelle A, Kloos RT. Hashimoto's thyroiditis with papillary thyroid carcinoma (PTC)-like nuclear alterations expresses molecular markers of PTC. Histopathology 2004;45:39-46.

12. Murphy KM, Chen F, Clark DP. Identification of immunohistochemical biomarkers for papillary thyroid carcinoma using gene expression profiling. Hum Pathol 2008;39:420-6.

13. Bartolazzi A, Orlandi F, Saggiorato E, Volante M, Arecco F, Rossetto R, et al. Galectin-3 expression analysis in the surgical selection of follicular thyroid nodules with indeterminate fine-needle aspiration cytology: a prospective multicentre study. Lancet Oncol 2008;9:543-9.

14. Papale F, Cafiero G, Grimaldi A, Marino G, Rosso F, Mian C, et al. Galectin-3 expression in thyroid fine needle cytology (t-FNAC) uncertain cases: validation of molecular markers and technology innovation. J Cell Physiol 2013;228:968-74.

15. Xue G, Liu J, Huang J, Zhang J, Zhang W, Wu J, et al. Detection of galectin-3 in both serum and tissue for early diagnosis of thyroid carcinoma. Nanfang Yike Daxue Xuebao 2013;33:1027-30.

16. Song Q, Wang D, Lou Y, Li C, Fang C, He X, et al. Diagnostic significance of CK19, TG, Ki67 galectin-3 expression for papillary thyroid carcinoma in the northeastern region of China. Diagn Pathol 2011;6:126.

17. Lee YS, Ha SA, Kim HJ, Shin SM, Kim HK, Kim S, et al. Minichromosome maintenance protein 3 is a candidate proliferation marker in papillary thyroid carcinoma. Exp Mol Pathol 2010;88:138-42.

18. Liu Z, Yu P, Xiong Y, Zeng W, Li X, Maiaiti Y, et al. Significance of CK19, TP0, and HBME-1 expression for diagnosis of papillary thyroid carcinoma. Int J Clin Exp Med 2015;8:4369-74.

19. de Matos LL, Del Giglio AB, Matsubayashi CO, de Lima Farah M, Del Giglio A, da Silva Pinhal MA. Expression of CK-19, galectin-3, and HBME-1 in the differentiation of thyroid lesions: a systematic review and diagnostic meta-analysis. Diagn Pathol 2012;7:97.

20. Dencic TM, Savin SB, Selemetjev SA, Paskas SD, Zivaljevic VR, Bozic VD, et al. a Strong expression of HBME-1 associates with high-risk clinicopathological factors of papillary thyroid carcinoma. Pathol Oncol Res 2015;21:735-42.

21. Ma H, Xu S, Yan J, Zhang C, Qin S, Wang X, et al. The value of tumor markers in the diagnosis of papillary thyroid carcinoma alone and in combination. Pol J Pathol 2014;65:202-9.

22. Isic Dencic T, Cvejic D, Paunovic I, Tatic S, Havelka M, Savin S. Cytokeratin19 expression discriminates papillary thyroid carcinoma from other thyroid lesions and predicts its aggressive behavior. Med Oncol 2013;30:362.

23. Bose D, Das RN, Chatterjee U, Banerjee U. Cytokeratin 19 immunoreactivity in the diagnosis of papillary thyroid carcinoma. Indian J Med Paediatr Oncol 2012;33:107-11.

24. Kaczka K, Fendler W, Borowiec M, Młynarski W, Celnik A, Pomorski L. Lymph node metastases in papillary thyroid cancer detected by quantitative real-time polymerase chain reaction for thyroglobulin and cytokeratine19. Pol J Pathol 2013;64:90-5.

25. Laco J, Ryska A, Cáp J, Celakovský P. Expression of galectin-3, cytokeratin 19, neural cell adhesion molecule and E-cadhedrin in certain variants of papillary thyroid carcinoma. Cesk Patol 2008;44:103-7.

26. Wu G, Wang J, Zhou Z, Li T, Tang F. Combined staining for immunohistochemical markers in the diagnosis of papillary thyroid carcinoma: improvement in the sensitivity or specificity? J Int Med Res 2013;41:975-83.

27. Yeşil C, Kandemir O, Haksever H, Dabakoğlu T. Is BECLIN-1 immunoreactivity more effective than HBME-1 in the diagnosis of papillary thyroid cancer? Acta Chir Belg 2015;115:299-305.

28. Barresi V, Leni A, Tuccari G, Barresi G. Neutrophil gelatinase associated lipocalin (NGAL) immunohistochemical expression in follicular cell-derived thyroid tumors: a novel diagnostic tool? Histol Histopathol 2012;27:329-36.

29. Ma H, Yan J, Zhang C, Qin S, Qin L, Liu L, et al. Expression of papillary thyroid carcinoma associated molecular markers and their significance in follicular epithelial dysplasia with papillary thyroid carcinoma-like nuclear alterations in Hashimoto's thyroiditis. Int J Clin Exp Pathol 2014;7:7999-8007.

30. Do SI, Kim DH, Yang JH, Pyo JS, Kim K, Lee H, et al. Decreased expression of p27 is associated with malignant transformation and extrathyroidal extension in papillary thyroid carcinoma. Tumour Biol 2016;37:3359-64.

31. Huang Y, Dong W, Li J, Zhang H, Shan Z, Teng W. Differential expression patterns and clinical significance of estrogen receptor- $\alpha$ and $\beta$ in papillary thyroid carcinoma. BMC Cancer $2014 ; 14: 383$.

32. Hao Y, Jin C, Wang J. Expression and clinical significance of Muc1, p63 protein in a diffuse sclerosing variant of papillary thyroid carcinoma and conventional papillary thyroid carcinoma. Lin Chung Er Bi Yan Hou Tou Jing Wai Ke Za Zhi 2013;27:457-61.

33. Yip L, Nikiforova MN, Yoo JY, McCoy KL, Stang MT, Armstrong $\mathrm{MJ}$, et al. Tumor genotype determines the phenotype and 
disease-related outcomes in thyroid cancer: a study of 1510 patients. Ann Surg 2015;262:519-25.

34. Xue G, Huang J, Zhang H, Zhang W, Wu J, Shang X. The expression and significance of trefoil factor 3 and SDF-1/CXCR4 biological axis in papillary thyroid carcinoma. Lin Chung Er Bi Yan Hou Tou Jing Wai Ke Za Zhi 2014;28:108-12.

35. Marecko I, Cvejic D, Selemetjev S, Paskas S, Tatic S, Paunovic I, et al. Enhanced activation of matrix metalloproteinase-9 correlates with the degree of papillary thyroid carcinoma infiltration. Croat Med J 2014;55:128-37.

36. Wang JR, Li XH, Gao XJ, An SC, Liu H, Liang J, et al. Expression of MMP-13 is associated with invasion and metastasis of papillary thyroid carcinoma. Eur Rev Med Pharmacol Sci 2013;17:427-35.

37. Rossi ED, Martini M, Bizzarro T, Capodimonti S, Cenci T, Lombardi CP, et al. (2015). Uncommon BRAF mutations in the follicular variant of papillary thyroid carcinoma: new insights. Cancer Cytopathol 2013;123:593-602.

38. Cheng Y, Meng Y, Liang Z, Yang C, Luo Y, Cui Q. Expression of EpCAM and E-cadherin in papillary thyroid carcinoma and its clinicopathologic significance. Zhonghua Bing Li Xue Za Zhi 2015;44:189-94

39. Prescott JD, Zeiger MA. The RET oncogene in papillary thyroid carcinoma. Cancer 2015;121:2137-46. 